\title{
The Constitutionality of the Individual Mandate for Health Insurance
}

\author{
Jack M. Balkin, J.D., Ph.D.
}

$\mathrm{O}$ nce President Barack Obama and Democrats in Congress have passed a health care reform bill, conservative groups are likely to challenge parts of it as unconstitutional, arguing that it oversteps Congress's powers. A key target will be the individual mandate, which is designed to coax uninsured persons into purchasing insurance.

The term "individual mandate" is misleading for two reasons. First, the law would not actually require all individuals to purchase insurance. The mandate would not apply to dependents, persons receiving Medicare or Medicaid, military families, persons living overseas, persons with religious objections, or persons who already get health insurance from their employers under a qualified plan.

Second, it is not actually a mandate. It is a tax, which people would not have to pay if they purchased health insurance. The House bill imposes a tax of $2.5 \%$ on adjusted gross income if a taxpayer is not part of a qualified health insurance program. The Senate bill imposes what is called an "excise tax" - a tax on transactions or events - or a "penalty tax" - a tax for failing to do something (e.g., filing your tax return promptly). The tax is levied for each month that an individual fails to pay premiums into a qualified health plan.

Congress has the power to pass legislation that falls within any of its powers enumerated in the Constitution. There are two obvious sources of congressional power. The first, described in the General Welfare Clause, is the power "to lay and collect taxes, duties, imposts and excises, to pay the debts and provide for the common defence and general welfare of the United States." The second, laid out in the Commerce Clause, is the power "to regulate commerce ... among the several states."

The individual mandate is a tax. Does it serve the general welfare? The constitutional test is whether Congress could reasonably conclude that its taxing and spending programs promote the general welfare of the country. ${ }^{1}$ This test is easily satisfied. The new health care reform bill insures more people and prevents them from being denied insurance coverage because of preexisting conditions. Successful reform requires that uninsured persons - most of whom are younger and healthier than average - join the national risk pool; this will help to lower the costs of health insurance premiums nationally.

Taxing uninsured people helps to pay for the costs of the new regulations. The tax gives uninsured people a choice. If they stay out of the risk pool, they effectively raise other people's insurance costs, and Congress taxes them to recoup some of the costs. If they join the risk pool, they do not have to pay the tax. A good analogy would be a tax on polluters who fail to install pollutioncontrol equipment: they can pay the tax or install the equipment.
Because the textual argument for Congress's authority under the General Welfare Clause is obvious and powerful, opponents have tried to argue that the tax is unconstitutional because it is a "direct" tax. Under the Constitution, "direct" taxes must be apportioned to state population. That is, if State A has twice as many people as State B, the amount of revenue collected from State A must be twice that collected from State B. Like most federal taxes, the individual mandate is not apportioned to state population.

The classic examples of direct taxes are taxes on real estate and capitation or "head" taxes on the general population, under which people are taxed no matter what they do. In one of the Supreme Court's first cases, Hylton v. United States, Justice William Paterson held that if there is any doubt, taxes should be classified as indirect rather than direct. ${ }^{2}$

The individual mandate is not a direct tax. The House's version is a tax on income. Under the Sixteenth Amendment, income taxes do not have to be apportioned, regardless of the source of the income. The Senate's version is an excise or penalty tax. It is neither a tax on real estate nor a general tax on individuals. It is a tax on events: individuals who are not exempted are taxed for each month they do not pay premiums to a qualified plan.

If the individual mandate falls within Congress's power to tax and spend, no other constitutional authority is necessary. However, 
Congress also has the power to impose the tax under the Commerce Clause. The test in this case is whether Congress could reasonably conclude that the economic activity it regulates has a substantial effect on interstate commerce when all individual instances of the regulated activity are added together. The Supreme Court says that economic activities include buying and selling, borrowing money, agriculture, services, manufacturing, and consumption.

Even if an activity is local and not economic, Congress can regulate it if it reasonably believes that doing so is necessary to make its regulation of commerce effective. $^{3}$ (Under the Constitution, Congress has the power to make all regulations that are "necessary and proper" for carrying out its enumerated powers.)

In 1942, the Supreme Court held that Congress could regulate wheat grown for home consumption as part of a general regulation of farm production. ${ }^{4}$ People who grew wheat at home substituted it for wheat products they would otherwise purchase in the market; cumulatively, this practice had a substantial effect on interstate farm prices. Similarly, in 2005, in Gonzales v. Raich, the Court held that Congress could regulate marijuana grown for home consumption as part of a general ban on controlled substances, because Congress reasonably concluded that people would substitute homegrown marijuana for other marijuana purchased in black markets. ${ }^{3}$

The individual mandate taxes people who do not buy health insurance. Critics charge that these people are not engaged in any activity that Congress might regulate; they are simply doing nothing. This is not the case. Such people actually self-insure through various means. When uninsured people get sick, they rely on their families for financial support, go to emergency rooms (often passing costs on to others), or purchase over-the-counter remedies. They substitute these activities for paying premiums to health insurance companies. All these activities are economic, and they have a cumulative effect on interstate commerce. Moreover, like people who substitute homegrown marijuana or wheat for purchased crops, the cumulative effect of uninsured people's behavior undermines Congress's regulation - in this case, its regulation of health insurance markets. Because Congress believes that national health care reform won't succeed unless these people are brought into national risk pools, it can regulate their activities in order to make its general regulation of health insurance effective.

One final argument against the individual mandate is that it violates the Fifth Amendment by allowing the government to take property without just compensation. "Takings" occur when the government seizes property from particular individuals; a familiar example is a local government's taking of land by eminent domain. Ordinary income taxes and excise taxes that are levied on a large population and that regulate people's behavior by taxing their income or consumption choices are not considered takings under the Constitution. The individual mandate is just such a tax - not a taking.

Although opponents will challenge the individual mandate in court, constitutional challenges are unlikely to succeed. The Supreme Court will probably not even consider the issue unless a federal court of appeals strikes the tax down. In that unlikely event, the Supreme Court will almost certainly uphold the tax, at least if it follows existing law. To strike down the individual mandate, it would have to reject decades of precedents. It is very unlikely that there are five votes on the current Court for staging such a constitutional revolution.

Financial and other disclosures provided by the author are available with the full text of this article at NEJM.org.

From Yale Law School, New Haven, CT.

This article (10.1056/NEJMp1000087) was published on January 13, 2010, at NEJM .org.

1. Helvering v. Davis, 301 U.S. 619 (1937).

2. Hylton v. United States, 3 U.S. 171 (1796).

3. Gonzales v. Raich, 545 U.S. 1 (2005).

4. Wickard v. Filburn, 317 U.S. 111 (1942).

Copyright (c) 2010 Massachusetts Medical Society. 